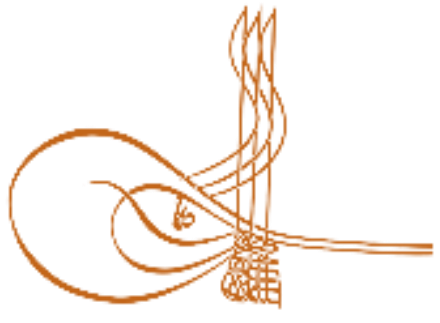

www.turkishstudies.net/social
Turkish Studies - Social Sciences

eISSN: $2667-5617$

Research Article / Araştırma Makalesi

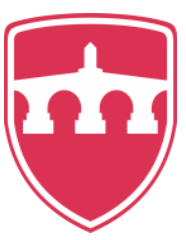

INTERNATIONAL BALKAN UNIVERSITY Sponsored by IBU

\title{
Borsa İstanbul ile Asya Pasifik Sermaye Piyasaları Arasındaki Eşbütünleşme Analizi: Panel ARDL Modeli
}

\author{
Cointegration Analysis Between Ise and Asia Pacific Capital Markets: Panel Ardl Model
}

\author{
Ozan Gönüllü*
}

\begin{abstract}
International portfolio investments allow minimizing systematic risk which cannot be eliminated by domestic portfolio investments. For successful international diversification, stock exchanges should not give the same reactions to the same developments, in other words, there should be no long-term relationships between them. The cointegration relationship negate the long-term effectiveness of traditional risk diversification techniques based on covariance. Long- and short-term relationships between stock exchanges in different geographies are important for investors who want to minimize portfolio diversification and / or increase profit by estimating the short-term fluctuations in these capital markets. Long-term relationships between capital markets are analyzed with cointegration models in finance literature. In this study, long-term and short-term relationships between BIST100 (XU100) indicator index of ISE and indicator indices of the largest capital markets of the Asia Pacific region (China Shanghai Stock Exchange SSE 100 Index, Japan Tokyo Stock Exchange Nikkei 225 Index, South Korean Stock Exchange KOSPI Index and New Zealand Stock Exchange NZX 50 Index) were analyzed. 132 monthly data between January 2009 and December 2019 were used in the study. According to the unit root test results of natural logarithmic time series, it was decided that the appropriate method for cointegration analysis was Autoregressive Distributed Lag Model (ARDL) developed by Pesaran et al (2001). The results of ARDL model indicate a statistically significant long term relationship between variables. After estimating long term coefficients, Error Correction Model (ECM) was used to determine short term relationships. The findings of the study revealed that the Korean Stock Exchange (KOSPI) and the New Zealand Stock Exchange (NZ50) had a positive and significant relationship with Borsa Istanbul (XU100) in the both long and short term. While the long-term relationship of the Japanese Stock Exchange (N225) with Borsa Istanbul was found to insignificant, but, in short term, significant relationship was found at significance level of $10 \%$. The Chinese Stock Exchange (SSE), which has no significant relationship with Borsa İstanbul in both long and short terms, stands out as the best international diversification alternative for an investor who has investments in Borsa Istanbul.
\end{abstract}

Structured Abstract: International portfolio investments have become more important as a result of the free movement of capital. International portfolio investments allow minimizing systematic risk which cannot be

\footnotetext{
* Dr., Kocaeli Üniversitesi İ̈BF, İşletme Bölümü

Phd., Kocaeli University, Faculty of Economics and Administrative Sciences, Department of Business

ORCiD https://orcid.org/0000-0001-9611-4499

ozangonullu@kocaeli.edu.tr

Cite as/ Atıf: Gönüllü, O. (2020). Borsa İstanbul ile Asya Pasifik Sermaye Piyasaları arasındaki eşbütünleşme analizi:

Panel Ardl Modeli, Turkish Studies - Social, 15(2), 221-238. https://dx.doi.org/10.29228/TurkishStudies.40612

Received/Geliş: 17 December/Aralık 2019

Accepted/Kabul: 25 February/Şubat 2020

Checked by plagiarism software

Copyright $(C)$ INTAC LTD, Turkey

Published/Yayın: 29 February/Şubat 2020

CC BY-NC 4.0
} 
eliminated by domestic portfolio investments. This has led to increased interest in capital markets in Europe, the United States and Asia with high transaction volumes. Investments in foreign stock exchanges add an international dimension to the diversification aimed to reduce portfolio risk. The integration of capital markets as a result of globalism led to a situation where economic and political developments in one country easily affect other countries' capital markets. Capital markets that do not have a cointegration relationship may play a role in minimizing risk. Therefore, the level of cointegration between capital markets and the long- and shortterm effects of the cointegration are important factors for international portfolio investors.

There are a lot of studies that which investigates the cointegration of capital markets and more specifically the cointegration relationship between the Turkish capital market and foreign capital markets. The models used in these studies usually include Johansen Cointegration Test, Engle-Granger Test, Granger Causality Test and Arch-Garch Models. This research contributes to the literature by revealing the existence of cointegration between a foreign capital market of different geography and the Turkish capital market using a different model which is Autoregressive Distributed Lag (ARDL).

The aim of the this study is to investigate the existence of cointegration between Borsa İstanbul and the biggest stock markets of Asia Pacific which are China Stock Exchange, Japanese Stock Exchange, South Korea Stock Exchange and New Zealand Stock Exchange and also find how do these stock exchanges affect each other in the short and long term. Borsa İstanbul 100 index was used as the dependent variable of the study while the main indices of the largest capital markets in the Asia-Pacific namely China Shanghai Stock Exchange SSE 100 Index, Japan Tokyo Stock Exchange Nikkei 225 Index, South Korea Tube KOSPI Index and New Zealand NZX 50 Index was used as explanatory variables. Index closing prices data of 132 months between January 2009 and December 2019 were used in the analysis.

The long-term relationships between variables are usually analyzed by cointegration tests. It is suggested that if the non-stationary Yt and Xt series become stationary at the same level, the Yt and Xt series may be cointegrated (Enders, 2014). There are many cointegration tests in order to examine long and shortterm relationships between indices of capital markets. Among the models used to analysis the cointegration relationship Engle-Granger Cointegration Test (Engle ve Granger, 1987) and the Johansen Cointegration Test (Johansen, 1988) does consist of two stages as cointegration and error correction stages. However, these models are based on the condition that all series are stationary at the same level. The stationarity of the series was analyzed by the Augmented Dickey-Fuller Test (ADF) which is a unit root test. The result of the analysis showed while some series are level stationary $\mathrm{I}(0)$, some other series only gets stationary I(I) when their first differences. Therefore, instead of the aforementioned methods, the Autoregressive Distributed Lag (ARDL) Model, which does not require the series to be stationary at the same level, is used in the analysis. The ARDL model is a regression model based on the least-squares method which estimates the lags lengths of the dependent and explanatory variables. The lag lengths of dependent and independent variables (p, q) are determined by using information criteria. In this study, the Akaike Information Criterion was used to determine the optimal lag lengths. The ARDL model consists of two stages. At first, the existence of cointegration gets investigated. If the findings indicate the existence of cointegration, long-term and short-term correlation coefficients are estimated. In the study, the estimated ARDL model with the appropriate lag lengths was evaluated by the Bounds Test. As the estimated F statistic found by the test results is exceeding the critical value developed by Pesaran et al. (2001), a cointegration between the series was supported. In the study, also, long term coefficients and short-term coefficients were estimated by using the ARDL Model and Error Correction Model respectively.

Unit Root (ADF) test results show while XU100 and KOSPI indices are stationary I(0) at level, N225, NZ50 and SSE indices are stationary at first differences. For the ARDL model, the lag lengths, determined according to Akaike Information Criterion, found as 1 for the variables of XU100, KOSPI, N225 and NZ50; 0 for the SSE variable. The F statistic obtained by the Bounds Test on ARLD model which designed with the specified optimal lag lengths were found as 4,0916. Since F statistic value exceeds the critical values calculated by Pesaran, Shin and Smith (2001) for the significance level $\% 5$ it is concluded there is cointegration, in other words, a long-term relationship between the stock exchanges included in the analysis.

The ARDL model includes long-term and short-term relationships. Therefore, long-term and shortterm correlation coefficients were estimated separately. According to the results of the analysis, Borsa İstanbul have positive and statistically significant relationship with South Korea Stock Exchange (KOSPI) at significance level of $1 \%$ and New Zealand Stock Exchange (NZ50) at significance level of 5\%. However, the

Turkish Studies - Social, 15(2) 
long-term relationships between Borsa Istanbul with Japanese Stock Exchange (N225) and the Chinese Stock Exchange (SSE) are insignificant.

In the next stage of the ARDL model the existence of a short-term relationship between indices was tested. For this purpose, an error correction model (ECT) has been designed by using the error terms of the long- term regression (ECT) as a variable. As a result of the analysis, it is concluded that there is a short-term relationship between Borsa İstanbul and Korea Stock Exchange at significance level of 1\%, New Zealand Stock Exchange at significance level of 5\% and Japanese Stock Exchange at significance level of 10\%. The shortterm relationship between Borsa Istanbul and the Chinese Stock Exchange was found to be statistically insignificant in parallel with the long-term relationship.

According to the results of the analysis, for international diversification, an investor who has invested in Borsa Istanbul may be advised to invest in the Japanese and / or Chinese Stock Exchange in the long term instead of the South Korea and New Zealand exchanges. In the short term, South Korea Stock Exchange, New Zealand Stock Exchange and Japanese Stock Exchange are dependent on Borsa Istanbul, so there is no possibility of diversification or abnormal returns in the short term. The Chinese Stock Exchange (SSE), which has no significant relationship with Borsa İstanbul in both long and short terms, stands out as the best international diversification alternative for an investor who has investments in Borsa Istanbul.

Keywords: Borsa Istanbul, Cointegration, Autoregressive Distributed Lag Model (ARDL), Error Corretion Model (ECM), Asia-Pacific Capital Markets

Öz: Uluslararası portföy yatırımları, yurtiçi portföy yatırımları ile ortadan kaldırılamayan sistematik riskin minimize edilmesine olanak sağlamaktadır. Başarılı bir uluslararası çeşitlendirme için yatırım yapılan borsaların aynı gelişmelere aynı tepkileri vermemesi, başka bir deyişle aralarında uzun dönemli ilişkiler bulunmaması gerekmektedir. Uluslararası sermaye piyasalarının eşbütünleşmesi, kovaryansa dayalı geleneksel çeşitlendirme yöntemlerinin uzun dönem etkinliğini ortadan kaldırmaktadır. Farklı coğrafyalarda yer alan borsalar arasındaki uzun ve kısa dönemli ilişkiler, portföy riskini uluslararası çeşitlendirme ile minimize etmek ve/veya söz konusu borsalardaki kısa dönem dalgalanmaları tahmin ederek getiri elde etmek isteyen yatırımcılar açısından önem arz etmektedir. Finans yazınında, sermaye piyasaları arasındaki uzun dönemli ilişkiler eşbütünleşme modelleri ile analiz edilmektedir. Bu çalışmada, Borsa İstanbul gösterge endeksi olan BIST100 (XU100) endeksi ile Asya Pasifik bölgesinin en büyük sermaye piyasalarının gösterge endeksleri (Çin Şangay Borsası SSE 100 Endeksi, Japonya Tokyo Borsası Nikkei 225 Endeksi, Güney Kore Borsası KOSPI Endeksi ve Yeni Zelanda NZX 50 Endeksi) arasındaki uzun ve kısa dönemli ilişkiler analiz edilmiş̧ir. Araştırmada, 2009 Ocak ile 2019 Aralık tarihleri arasındaki 132 aylık veri kullanılmıştır. Doğal logaritması alınan zaman serilerinin birim kök test sonuçları sonuçlarına göre, eşbütünleşme analizi için uygun yöntemin Pesaran vd. (2001) tarafından geliştirilen Gecikmesi Dağıtılmış Otoregresif Model (Autoregressive Distributed Lag Model - ARDL) olduğuna karar verilmiştir. Kurulan ARDL modeli sonucunda değişkenler arasında uzun dönemli ilişkinin istatistiksel olarak anlamlı olduğu sonucuna ulaşılmıştır. Uzun dönem katsayıların tahmin edildikten sonra, kısa dönemli ilişkilerin belirlenebilmesi için Hata Düzeltme Modeli (Error Correction ModelECM) kullanılmıştır. Araştırmanın bulguları, hem uzun hem de kısa dönemde, Borsa İstanbul (XU100) ile Kore Borsası (KOSPI)'nın \%1 anlamlılık düzeyinde; Yeni Zelanda Borsası (NZ50)'nın ise \%5 anlamlılık düzeyinde pozitif ve anlamlı bir ilişkiye sahip olduğunu ortaya koymuştur. Japon Borsası (N225)'ın, Borsa İstanbul ile uzun dönemli ilişkisi anlamlı bulunmazken, kısa dönemli ilişkisi $\% 10$ anlamlılık düzeyinde anlamlı bulunmuştur. Hem uzun hem kısa dönemde Borsa İstanbul ile ilişkisi anlamlı bulunmayan Çin Borsası (SSE) ise Borsa İstanbul'da yatırımları bulunan bir yatırımcı için en iyi uluslararası çeşitlendirme alternatifi olarak göze çarpmaktadır.

Anahtar Kelimeler: Borsa İstanbul, Eşbütünleşme, Gecikmesi Dağıtılmış Otoregresif Model (ARDL), Hata Düzeltme Modeli (ECM), Asya-Pasifik Sermaye Piyasaları

\section{Giriş}

Sermaye piyasalarına yatırım yapan rasyonel yatırımcıların temel amaçlarından biri, toplam riski olabildiğince düşürecek şekilde çeşitlendirilmiş bir menkul kıymet portföyü oluşturmaktır. 
Riskten korunmanın temel yolu; yatırımları, birbiri ile pozitif korelasyonu bulunmayan menkul kıymetler arasında dağıtmaktır. Bir ülkenin sermaye piyasasında işlem gören tüm hisse senetleri, başta ülke riski olmak üzere aynı sistematik risk faktörlerinden etkilenmektedirler. Dolayısı ile salt yurtiçi sermaye piyasalarına yapılacak yatırımlar ile sistematik riskin azaltılması mümkün gözükmemektedir. Aynı getiriyi sağlayacak daha düşük riske sahip ya da aynı risk düzeyinde daha çok getiri sağlayacak portföyler oluşturmanın yolu uluslararası portföy yatırımlarından geçmektedir.

Uluslararası portföy yatırımlarına artan eğilimin temelde iki dayanağı bulunmaktadır. Bunlardan ilki, küresel sermaye akımlarının serbestleşmesinin, özellikle 80'li yıllardan sonraki trendi ile ilgilidir. 1975 ten sonra birçok ülke, yabancı sermayenin ülke içine girmesini sağlamak için deregülasyonlar ile finansal serbestleşme akımına dahil olmuştur. Uluslararası piyasalara girmenin önündeki ticaret engelleri azaldıkça, farklı ülkelerin sermaye piyasaları birbiri ile bağlantı kurmaya başlamıştır. $\mathrm{Bu}$ durum bir piyasayı etkileyen gelişmelerin, bulaşma etkisi ile diğer piyasaları etkilemeye başlaması; dolayısı ile bir piyasanın diğerinin öncüsü veya takipçisi olması anlamına gelmektedir. Uluslararası portföy yatırımlarına artan eğilimin diğer temel dayanağı ise küreselleşme ve teknolojik gelişmeler sonucu, kurumsal ve bireysel yatırımcıların uluslararası borsalara yatırım yapmasını kolaylaştıran bir iletişim ağının kurulmuş olmasıdır. Sermayenin sınırlardan geçişinin kolaylaşması, dünyayı finansal ve ekonomik olarak entegre etmekte; artan bu entegrasyon finansal işlem hacmini ve verimliliği artırırken borsaların birbiriyle olan korelasyonunu da artırmaktadır. Artan korelasyon ise uluslararası çeşitlendirmenin etkisini azaltmaktadır.

Teknolojik gelişmeler, işlem maliyetlerinin düşmesi, borsa işlemlerinin tamamen elektronik ortama taşınması gibi gelişmelerle beraber coğrafi uzaklıklar uluslararası sermaye piyasası yatırımcıları için önemini yitirmeye başlamıştır. Uluslararası portföy yatırımı yapmak ve/veya yatırımlarını korumak (hedging) isteyen yatırımcılar için yerel borsalar ile yabancı borsalar arasındaki korelasyon önemlidir. Risk, negatif korelasyonu olan varlıkları seçerek minimize edilebilir. Yatırımcilar önce negatif korelasyona sahip hisse senetlerini seçerek portföy çeşitlendirmesi yapar. Bu şekilde yapılan şirket çeşitlendirmesinin faydası tatmin edici olmazsa, yatırımcılar, endüstri düzeyinde çeşitlendirme ve son olarak da uluslararası çeşitlendirme yoluna gideceklerdir. Dolayısıyla, iyi çeşitlendirilmiş bir portföy oluşturmak için yatırımcı, farklı borsa getirileri arasındaki ilişkiyi bilmelidir. Bu sebeple borsalar arasındaki uzun ve kısa dönemli ilişkileri araştıran çalışmalar literatüre eklenmektedir.

Borsalar arasındaki uzun ve kısa dönemli ilişkileri belirleme amacını güden bu çalışmada, artan öneme sahip olan ve dünya sermaye piyasalarının toplam değerinin yaklaşı \%30'una sahip olan Asya Pasifik sermaye piyasaları ile Türk sermaye piyasası arasındaki olası eşbütünleşme araştırılmıştır. Literatürde incelendiğinde Türk Borsası ile genellikle gelişmekte olan ülkeler, Latin ülkeleri veya Avrupa ülkeleri arasındaki ilişkilerin incelendiği görülmektedir. Bu çalışmada, Asya Pasifik piyasalarına yatırım yaparak, Türkiye'de yapmış olduğu sermaye piyasası yatırımlarını korumak (hedge) isteyen yatırımcılara, hangi piyasaların uygun olabileceği hakkında bilgi vermek amacıyla Borsa İstanbul ile Çin, Japonya, Güney Kore ve Yeni Zelanda borsaları arasındaki ilişkiler, 2009-2019 yılları arasındaki aylık veriler kullanılarak analiz edilmiştir. Gecikmesi Dağıtılmış Otoregresif Model (Autoregressive Distributed Lag Model - ARDL) ve Hata Düzeltme Modeli (Error Correction Model - ECM) kullanılarak söz konusu borsalar arasındaki uzun ve kısa dönemli ilişkiler belirlenmiştir. Araştırmanın ilerleyen bölümlerinde daha önce yapılmış ampirik çalışmaların yöntem, veri seti ve sonuçlarına yer verildikten sonra, bu araştırmada kullanılan yöntemler açıklanmıştır. Araştırmanın son bölümünde ise yapılan ampirik çalışmanın bulgularına yer verilmiştir.

\section{Literatür}

Borsa endeks verilerinin zaman serisi özelliklerine dayanarak, uluslararası finansal piyasaların, bağımlılığını ve entegrasyon derecesini, eşbütünleşme analizleri yoluyla inceleyen geniş bir literatür bulunmaktadır. Yapılan ilk çalışmalar sermaye piyasaları arasındaki ilişkiyi korelasyon 
analizi ile ortaya koyarken, son dönemde yapılan çalışmalarda ise Johansen Testi, Engle-Granger Testi, Granger Nedensellik Testi, Arch-Garch Modelleri, Vektör Otoregresif Model (VAR), Hata Düzeltme Modeli ve ARDL Modeli gibi yöntemler kullanılmaktadır. Dünya sermaye piyasaları arasındaki eşbütünleşmeyi konu alan çalışmalar aşağıdaki gibi özetlenebilir:

Kasa (1992), Johansen Eşbütünleşme metodolojisini kullanarak, ABD, Japonya, İngiltere, Almanya ve Kanada hisse senedi piyasalarının Ocak 1974 - Ağustos 1990 dönemindeki aylık ve mevsimlik kapanış verilerini analiz etmiştir. Araştırmanın sonuçları, söz konusu ülkelerin borsalarını yönlendiren tek bir ortak stokastik eğilimin varlığını göstermektedir. Ortak stokastik trend çalışmalarından bir diğeri Taufiq vd. (2007) tarafından yapılmıştır. Çalışmada, 1997-98 Asya ekonomik krizini merkez alarak, sekiz Uzak Doğu ülkesinin hisse senedi endeksleri arasındaki uzun dönemli ilişkilerin değişimi Johansen Eşbtünleşme Testi ile araştırılmıştır. Araştırmanın bulguları, kriz öncesi, sırası ve sonrasında Uzak Doğu sermaye piyasaları arasında uzun vadeli ilişki olduğunu oraya koymuştur. Jochum vd. (1999), 1995-1998 yılları arasında Doğu Avrupa borsalarının fiyat verilerini analiz etmişlerdir. Çalışmada, söz konusu borsalar arasında 1997/98 piyasa krizinin oluşmasını ve yayılmasını sağlayan uzun vadeli ilişkiler olduğu, ancak kriz sırasında ve kriz sonrası ortak stokastik eğilimin kaybolduğu sonucuna ulaşılmıştır.

Choudhry (1997), altı Latin Amerika ülkesinin gösterge endeksleri ile ABD borsaları arasındaki uzun vadeli ilişkiyi, 1989-1993 arasındaki verileri Johansen metodolojisi analiz etmiş ve uzun dönem için istatistiksel olarak anlamlı bağlantılar tespit etmiştir. Ayrıca kısa dönemli ilişkiler hakkında bilgi veren hata düzeltme modeli sonuçları da söz konusu endeksler arasında önemli nedensellikler olduğuna işaret etmektedir.

Chan, vd. (1997), 1961-92 dönemi için birim kök ve eşbütünleşme testlerini kullanılarak, 18 farklı borsadaki hisse senedi endeks kapanış fiyatları arasındaki ilişkiyi incelemiştir. Eşbütünleşme testi sonuçları, son otuz yılda az sayıda önemli eşbütünleşme vektörü olduğunu göstermektedir. Bununla birlikte, 1987 borsa çöküşünden sonra önemli eşbütünleşme vektörlerinin sayısının artmakta olduğu ve bu durumun bulaşma etkisiyle tutarlı olduğu sonucuna varmışlardır.

Yang vd. (2003), 1970-2001 arasındaki 384 aylık gözlemi kullanarak ABD ve 14 gelişmiş ülke arasındaki uzun vadeli ilişkiyi araştırmışlardır. Japonya, Birleşik Krallık, Almanya gibi gelişmiş sermaye piyasaları ile ABD borsası arasında uzun dönemli ilişkiye rastlanmazken, nispeten küçük sermaye piyasaları ile ABD borsası arasında artan uzun dönemli ilişki bulgusuna rastlanmıştır.

Gilmore ve McManus (2003) Almanya borsası ile Çekya, Macaristan ve Polonya borsaları arasında eşbütünleşme olup olmadığını belirlemek için 1995 - 2000 yılları arasındaki haftalık verileri, Johansen metodolojisi ile analiz etmişlerdir. Alman ve Orta Avrupa sermaye piyasaları arasında bireysel veya grup olarak uzun vadeli bir ilişki olmadığı sonucuna ulaşmışlardır.

Narayan ve Smyth (2005), Yeni Zelanda ile Avustralya ve G-7 ekonomileri arasindaki eşbütünlemeyi incelemek için hem Johansen hem de Gregory\&Hansen testini kullanmıştır. Araştırmanın sonuçlarına göre Johansen metodolojisini kullanarak herhangi bir eşbütünleşme bulgusuna ulaşılamazken, Gregory ve Hansen metodolojisini kullanarak yapısal kırılma analizleri sonucunda Yeni Zelanda ve Amerika Birleşik Devletleri borsalarının eşbütünleştiği bulgusuna ulaşılmıştır.

Hallgren ve Rehn (2011), 2000 - 2011 yılları arasını kapsayan çalışmalarında Avrupa'nın altı majör hisse senedi endeksi arasındaki eşbütünleşme ilişkisini araştırmışlardır. Endeksler arasında uzun dönemli ilişkiye ait ortak bir vektörün varlığı bulgusuna ulaşmışlardır. Bu durumu, analize dahil edilen borsaların aynı uzun vadeli büyüme yolunu izlediğini ve hiçbir borsanın zaman içinde önemli ölçüde daha iyi veya daha kötü göreceli performansa sahip olmayacağı şeklinde yorumlamışlardır.

Khan (2011), ABD sermaye piyasası ile gelişmiş ve gelişmekte olan 22 ülkenin sermaye piyasası arasındaki uzun dönem ilişkileri, Johansen ve Gregory\&Hansen testlerini kullanarak analiz 
etmiştir. Günlük endeks kapanış verilerinin kullanıldığı çalışmanın sonuçlarına göre; Çin, Malezya ve Avusturya sermaye piyasalarının, ABD sermaye piyasası ve küresel endekse duyarsız oldukları için son derece elverişli çeşitlendirme firsatlarına sahip piyasalar olarak öne çıktıkları sonucuna ulaşmışlardır.

Thangamuthu ve Karthikeyan (2015), Güney Afrika, Hindistan ve ABD borsaları arasındaki uzun ve kısa dönemli ilişkileri araştırmak amacı ile ilgili ülke endekslerinin 2004 - 2014 arası aylık kapanış verilerini Johansen ve Juselius çok değişkenli eşbütünleşme yaklaşımı ile analiz etmişlerdir. Araştırma sonuçları, üç borsa endeksi arasında uzun vadeli bir ilişkinin olmadığını göstermektedir. Kısa dönemli ilişki analizi için ise Vektör Otoregresif Model (VAR) modeli kullanılmış ve hem ABD'nin hem de Güney Afrika borsalarının yalnızca kendi geçmiş gecikmeleri tarafından tahmin edilebildiği sonucuna ulaşılmıştır.

Borsa İstanbul (BIST) ya da eski adı ile İstanbul Menkul Kıymetler Borsası (IMKB) ile yabancı ülkelerin sermaye piyasaları arasındaki eşbütünleşme analizini araştıran çalışmalar ise şöyledir:

Vuran (2010), İstanbul Menkul Kıymetler Borsası'nın gösterge endeksi olan İMKB100 Endeksi ile, S\&P500 Endeksi (ABD), Nikkei 225 Endeksi (Japonya), DAX Endeksi (Almanya), FTSE 100 Endeksi (İngiltere), CAC 40 Endeksi (Fransa), Bovespa Endeksi (Brezilya), Merval Endeksi (Arjantin) ve IPC Endeksi (Meksika) arasındaki eşbütünleşme ilişkisini Johansen Eşbütünleşme Testi ile analiz etmiştir. 2006-2009 tarihleri arasındaki günlük endeks kapanış verilerinin kullanıldığı çalışmada, IMKB 100 endeksine yatırım yapan yatırımcılar için S\&P500, Nikkei 225 ve CAC 40 endekslerinin portföy çeşitlendirmesi için uygun alternatifler olduğu, diğer endeksler ile IMKB100 Endeksi arasında uzun dönem ilişkiler bulunduğu sonucuna ulaşılmıştır.

Bozoklu ve Saydam (2010) Türkiye borsası ile BRIC ülkeleri olarak tanımlanan Brezilya, Çin, Hindistan ve Rusya borsaları arasındaki eşbütünleşme ilişkilerini, 2005 - 2010 dönemindeki endeks verilerini kullanarak, Johansen ve Bierens eşbütünleşme testleri ile analiz etmiş ve söz konusu ülkelerin borsalarının birbiri ile uzun dönemli ilişkiye sahip olduğu ve uzun dönemde normal üstü kâr elde etme olanağının bulunmadığı sonucuna ulaşmışlardır.

Gözbaşı (2010), Arjantin, Brezilya, Meksika, Hindistan, Malezya, Macaristan ve Misır sermaye piyasaları ile Türkiye sermaye piyasası arasındaki eşbütünleşme ilişkisini araştırdığı çalışmasında, 1995-2008 yılları arasındaki haftalık endeks kapanış verilerini Gecikmesi Dağıtılmış Otoregresif Model (ARDL), Granger Nedensellik Testi ve Toda-Yamamoto Nedensellik Testi ile analiz etmiştir. Türk sermaye piyasası ile Mısır, Hindistan ve Brezilya sermaye piyasalarının eşbütünleşik bulunduğu çalışma sonuçlarına göre Meksika ve Macaristan borsaları ile İMKB arasında kısa dönemli ilişkiler bulunmuştur. Türkiye borsası ile Malezya ve Arjantin borsası arasındaki kısa ve uzun dönemli ilişkiler ise istatistiksel olarak anlamlı bulunmamıştır.

Boztosun \& Çelik (2011), Avrupa borsaları ile Türkiye borsası arasındaki eşbütünleşme ilişkisini araştırdıkları çalışmalarında, Johansen-Jeselius eşbütünleşme modelini kullanarak 2002 2009 yılları arasındaki verileri analiz etmişlerdir. Çalışma sonuçlarına, göre Türkiye ile İsveç, Fransa, İsviçre ve İspanya borsaları arasında eşbütünleşme bulgusuna rastlanmazken; Türk borsasının, Almanya, İngiltere, Hollanda, Norveç ve Belçika borsaları ile eşbütünleşik olduğu sonucuna ulaşı1mıştır.

Bulut \& Özdemir (2012), Eski adı ile İstanbul Menkul Kıymetler Borsası ile Dow Jones Endüstri endeksi arasındaki ilişkileri Granger Nedensellik Testi ve Johansen Eşbütünleşme Testi ile analiz etmişlerdir. Ocak 2001 ile Aralık 2010 dönemi arasındaki haftalık endeks kapanış verilerinin kullanıldığı çalışmanın sonuçlarına göre Dow Jones Endüstri Endeksi'nin üç gecikme için İMKB endeksinin Granger nedeni olduğu ve söz konusu endekslerin eşbütünleşik olduğu sonucuna 
varılmıştır. Kısa dönemli ilişkiler Vektör Hata Düzeltme Modeli ile analiz edilmiş ve istatistiksel olarak anlamlı bulunmuştur.

Ergün vd. (2012), Türkiye sermaye piyasası ile Kuzey Afrika ve Ortadoğu sermaye piyasaları arasındaki eşbütünleşmeyi araştırmışlardır. Aylık verilerin ve Johansen Eşbütünleşme metodolojisinin kullanıldığı çalışmada Türkiye borsası ile İsrail, Mısır, Umman ve Katar borsaları arasında uzun dönemli ilişki olduğu bulgusuna ulaşılmıştır.

Akel (2015), "Fragile Five" olarak adlandırılan Brezilya, Endonezya, Güney Afrika, Hindistan ve Türkiye sermaye piyasalarının 2010-2013 yılları arasındaki haftalık kapanış verilerini, Johansen Eşbütünleşme Modeli ve Vektör Hata Düzeltme Modeli ile analiz ettiği çalışmasında; beş ülkenin sermaye piyasaları arasında kısa ve uzun dönemli entegrasyon ve nedensellik ilişkisi olduğu sonucuna ulaşmıştır.

Geyikçi (2017), Asya, Avrupa ve Amerika kıtasından seçilen 12 sermaye piyasasının, Borsa İstanbul ile olan eşbütünleşme ilişkisinin belirlenmesi amacı ile 2002 - 2017 yılları arasındaki 176 gözlemden oluşan aylık verileri, Johansen Eşbütünleşme Testi, Vektör Hata Düzeltme Modeli ve Granger Nedensellik Testi ile analiz etmiştir. Araştırma sonucunda, analize dahil edilen tüm borsaların uzun dönem ilişkilere sahip olduğu ortaya koyulmuştur. Kısa dönemde ise BIST'in Tayland, Rusya, Polonya ve Brezilya borsaları ile karşılıklı, Tayvan, Malezya ve Çekya borsalarıyla ise tek yönlü bir nedensellik ilişkisine sahip olduğu tespit edilmiştir.

Akıncı ve Küçükçaylı (2018) Asya ve Avrupa borsalarının birbirileri ile olan ilişkilerini belirlemek amacı ile 2001-2017 tarihleri arasındaki aylık endeks verilerini incelemişlerdir. Yapısal kırılmalı zaman serisi analizlerinin kullanıldığı çalışmanın sonucunda, Avrupa borsaları ile Asya Pasifik borsaları arasında uzun dönemli pozitif yönlü ilişkiler olduğu ortaya koyulmuştur.

Gökmen ve Çömlekçi (2018), Turizm geliri yüksek olan ülkelere ait, seçilmiş 12 turizm endeksi ile Borsa İstanbul Turizm Endeksi arasındaki eşbütünleşme ilişkisini, 2011 - 2016 tarihleri arasındaki günlük verileri kullanarak Johansen Eşbütünleşme metodolojisi ile analiz etmiştir. Analiz sonucunda Türk borsasının turizm endeksi ile İspanya, Tayvan ve Yunanistan borsalarının turizm endekslerinin eşbütünleşik olduğu sonucuna ulaşılmıştır.

\section{Veri Seti ve Ekonometrik Model}

Çalışmada Borsa İstanbul ile Asya-Pasifik ülkelerinin sermaye piyasaları arasındaki uzun ve kısa dönemli ilişkiler incelenmiştir. Borsa İstanbul BIST100 Endeksi, Çin Şangay Borsası SSE 100 Endeksi, Japonya Tokyo Borsası Nikkei 225 Endeksi, Güney Kore Borsası KOSPI Endeksi ve Yeni Zelanda NZX 50 Endeksi'nin dahil edildiği bu çalışmada, 2009 - 2019 yılları arasındaki aylık veriler kullanılmıştır. 132 aylık endeks serileri doğal logaritmaları alınarak analiz edilmiştir. Çalışmada Eviews paket programı kullanılmıştır.

Değişkenler arasındaki uzun dönem ilişkilerin analizinde eşbütünleşme testleri kullanılmaktadır. Enders (2014), durağan olmayan $\mathrm{Y}_{\mathrm{t}}$ ve $\mathrm{X}_{\mathrm{t}}$ serileri eğer aynı düzeyde durağan hale geliyor ise $Y_{t}$ ve $X_{t}$ serilerinin eşbütünleşik olabileceğini öne sürmektedir. Sermaye piyasaları endekslerinin uzun ve kısa dönemli ilişkilerini incelemek amacı ile birçok eşbütünleşme testi kullanılmaktadır. Eşbütünleşme testi sonucunda $Y_{t}$ ve $X_{t}$ tarafindan oluşturulan denklemin hata terimleri durağanlaşırsa, söz konusu eşbütünleşik seriler arasında uzun dönemli bir ilişki olduğu bahsedilebilir. Bu ilişkinin araştırılması amacı ile en sık kullanılan modeller, eşbütünleşme ve hata düzeltme aşamalarından oluşan iki aşamalı Engle-Granger Eşbütünleşme Testi (Engle ve Granger, 1987) ve Johansen Eşbütünleşme Testi'dir (Johansen, 1988). Her iki testin de uygulanabilmesi için analize dahil edilen serilerin aynı düzeyde durağan olması gerekmektedir. Yani serilerden biri, düzey derecede durağanken (I(0)); diğer seri, birinci farkları alındığında durağan hale geliyor ise (I(1)), bu iki seri arasındaki uzun ve kısa dönemli ilişkilerin incelenmesi amacı ile söz konusu testler 
uygulanamamaktadır. Zaman serileri ile yapılan çalışmalarda bu kısıt genellikle söz konusu yöntemlerin kullanılabilmesini engellemektedir.

ARDL (Autoregressive Distributed Lag Model - ARDL) Sınır Testi, değişkenlerin I(0) veya I(1) olduğu varsayımına dayanmaktadır. Bu yaklaşımın en büyük avantajı, çoklu eşbütünleşme vektörlerinin varlığında uygulanabilmesidir. Başka bir deyişle ARDL Modeli Johansen ve EngleGranger Modellerinin aksine serilerin aynı düzeyde durağan olması şartını aramamaktadır Ancak, model ikinci düzeyde durağanlaşan serilerin I(2) varlığında çalışmamaktadır (Nkoro ve Uko, 2016: 64). Bu nedenle, ARDL testini uygulamadan önce, birim kök testlerini kullanarak tüm değişkenlerin durağanlık seviyelerinin belirlenmesi gerekmektedir (Belloumi, 2014: 277). Çalışmada Serilerin durağanlığının test edilmesi amacı ile birim kök testlerinden ADF (Augmented Dickey Fuller) testi uygulanmıştır.

ARDL Modeli, bağımlı ve açıklayıcı değişkenlerin optimal gecikmelerini içeren ARDL denkleminin en küçük kareler yöntemi ile tahmin edilmiş bir regresyon modelidir. Bağımlı ve bağımsız değişkenler için en uygun gecikme uzunluklarının (p,q) ne olacağına bilgi kriterleri kullanılarak karar verilir. Çalışmada, optimal gecikme uzunluğunun bulunabilmesi amacı ile Akaike Bilgi Kriteri (AIC - Akaike Information Criterion) kullanılmıştır.

ARDL testi iki adımda uygulanmaktadır. İlk adımda, Pesaran vd. (2001) tarafından önerilen Sınır (Bounds) Test kullanılarak uzun dönemli ilişkinin varlığı araştırılmaktadır. Uzun dönem ilişkinin varlığ durumunda ikinci aşamaya geçilmektedir. İkinci aşamada ise uzun ve kısa dönemli ilişkilere ait parametreler tahmin edilmektedir (Nkoro \& Uko, 2016: 79).

ARDL modelinde bağımlı değişken olarak Borsa İstanbul BİST100 Endeksi (XU100) kapanış fiyatlarının doğal logaritması kullanılmıştır. Açıklayıcı değişkenler ise Çin Şangay Borsası SSE 100 Endeksi, Japonya Tokyo Borsası Nikkei 225 Endeksi, Güney Kore Borası KOSPI Endeksi ve Yeni Zelanda NZX 50 Endeksinin kapanış fiyatlarının doğal logaritmaları şeklinde belirlenmiştir.

Fark operatörü $\Delta$; hata terimi $\varepsilon$; sabit terim $\alpha$; kısa dönemli ilişki katsayıları $\emptyset, \vartheta, \Omega, \gamma$ ve $\varphi$; uzun dönemli ilişki katsayıları $\lambda_{\mathrm{k}}$; bağımlı değişken gecikme uzunluğu $\mathrm{p}$, açıklayıcı değişken gecikme uzunlukları $\mathrm{q}_{\mathrm{k}}$ ile gösterilirse, çalışmada kullanılan ARDL modeli şu şekilde ifade edilebilir:

$$
\begin{aligned}
\Delta X U 100_{t}=\alpha_{0} & +\sum_{i=1}^{p} \emptyset_{i} \Delta X U 100_{t-i}+\sum_{i=1}^{q_{1}} \vartheta_{i} \Delta K O S P I_{t-i} \\
& +\sum_{i=1}^{q_{2}} \Omega_{i} \Delta N 225_{t-i}+\sum_{i=1}^{q_{3}} \gamma_{i} \Delta N Z 50_{t-i}+\sum_{i=1}^{q_{4}} \varphi_{5 i} \Delta S S E_{t-i}+\lambda_{1} X U 100_{t-1} \\
& +\lambda_{2} \operatorname{KOSPI}_{t-1}+\lambda_{3} N 225_{t-1}+\lambda_{4} N Z 50_{t-1}+\lambda_{5} S S E_{t-1}+\varepsilon_{t}
\end{aligned}
$$

ARDL modeli ile oluşturulan eşitlik, en küçük kareler yöntemi ile regresyon analizine tabi tutulur. Oluşturulan ARDL modelinin tanı testleri yapılarak uygunluğu test edilir. Regresyon sonuçlarının tutarlı olması için hata terimleri normal dağılmalı, otokorelasyon ve değişen varyans (Heteroscedasticity) problemleri bulunmamalıdır. Tanı testlerinin hipotezleri şu şekildedir: 


\begin{tabular}{|c|c|c|c|}
\hline Hipotezler & Normallik & Otokorelasyon & Değişen Varyans \\
\hline $\mathbf{H}_{\mathbf{0}}$ & $\begin{array}{l}\text { Hata terimleri normal } \\
\text { dağılmaktadır. }\end{array}$ & $\begin{array}{l}\text { Hata terimleri arasinda } \\
\text { otokorelasyon yoktur. }\end{array}$ & $\begin{array}{l}\text { Hata terimleri sabit varyansa } \\
\text { sahiptir. }\end{array}$ \\
\hline $\mathbf{H}_{1}$ & $\begin{array}{l}\text { Hata terimleri normal } \\
\text { dağılmamaktadır. }\end{array}$ & $\begin{array}{l}\text { Hata terimleri arasında } \\
\text { otokorelasyon vardır. }\end{array}$ & $\begin{array}{l}\text { Hata terimleri sabit varyansa } \\
\text { sahip değildir. }\end{array}$ \\
\hline
\end{tabular}

Oluşturulan ARDL modelinin tanı testleri sonucunda $\mathrm{H}_{0}$ hipotezi reddedilirse, modelin uzun dönem ilişkiyi temsil eden katsayılarının testine geçilebilir. Bu işlem Sınır (Bounds) Testi olarak adlandırılmaktadır. Değişkenler arasında eşbütünleşme olup olmadığının test edilmesi için optimum gecikme aralıkları ile tahmin edilen ARDL modelinin katsayılarının sıfırdan anlamlı bir şekilde farklı olup olmağı belirlenir. Sınırlandırılmamış Hata Düzeltme Modelinde (UECM) gecikmeli uzun dönem katsayılarının önemini kontrol etmek için F-istatistiği kullanılır (Pesaran ve Shin, 1999). Çalışmada, katsayıların test edilmesi amacıyla Wald Test F-istatistiği kullanılmıştır.

Wald Test'in hipotezleri şu şekildedir:

$$
\begin{aligned}
& \mathrm{H}_{0}=\lambda_{1}=\lambda_{2}=\lambda_{3}=\lambda_{4}=\lambda_{5}=0 \text { (Eşbütünleşme Yoktur.) } \\
& \mathrm{H}_{1}=\lambda_{1} \neq \lambda_{2} \neq \lambda_{3} \neq \lambda_{4} \neq \lambda_{5} \neq 0 \text { (Eşbütünleşme Vardır.) }
\end{aligned}
$$

Katsayıların anlamlı olup olmadığının belirlenebilmesi için Sınır Testi sonucunda ortaya çıan F-istatistik değeri ise Pesaran vd. (2001) tarafindan belirlenen asimptotik kritik değerler ile karşılaştırılır. Eğer hesaplanan $\mathrm{F}$ değeri, kritik değerlerin üst sınırından büyük ise sıfır hipotezi reddedilir. Bu sonuç, seriler arasında eşbütünleşmeyi, başka bir deyişle uzun dönem ilişkinin varlığını desteklemektedir. Bu durumda kısa dönemli ilişkiler, kurulacak model ile tahmin edilebilir. Eğer F değeri, kritik değerlerin altında ise sıfır hipotezi kabul edilir. Bir başka deyişle değişkenler arasında uzun dönem ilişki bulunmamaktadır. Eğer $F$ istatistik değeri, kritik değerlerin alt sınırı ile üst sınırı arasında yer alıyorsa, test sonuçsuz kabul edilir.

Analizin ikinci kısmı olan uzun ve kısa dönemli ilişki analizinin yapılabilmesi için eşbütünleşmenin varlığına ihtiyaç vardır. Sınır testi sonucunda eşbütünleşmenin varlığı ile ilgili bulgulara ulaşılırsa uzun dönem katsayıları ve kısa dönem katsayıları tahmin edilecektir. Uzun dönem katsayıları aşağıdaki regresyon denklemi ile tahmin edilir.

$$
\begin{aligned}
X U 100_{t}=\alpha_{0} & +\sum_{i=1}^{p} \alpha_{1 i} X U 100_{t-i}+\sum_{i=1}^{q_{1}} \alpha_{2 i} N 225_{t-i}+\sum_{i=1}^{q_{2}} \alpha_{3 i} N 225_{t-i}+\sum_{i=1}^{q_{3}} \alpha_{4 i} N Z 50_{t-i} \\
& +\sum_{i=1}^{q_{4}} \alpha_{5 i} S S E_{t-i}+\varepsilon_{t}
\end{aligned}
$$

Uzun dönem katsayılar belirlendikten sonra, aşağıdaki hata düzeltme modeli kullanılarak kısa dönemli ilişki katsayıları tahmin edilir: 


$$
\begin{aligned}
\Delta X U 100_{t}=\alpha_{0} & +\sum_{i=1}^{p} \emptyset_{1 i} \Delta X U 100_{t-i}+\sum_{i=1}^{q_{1}} \vartheta_{i} \Delta K O S P I_{t-i}+\sum_{i=1}^{q_{2}} \Omega_{i} \Delta N 225_{t-i}+\sum_{i=1}^{q_{3}} \gamma_{i} \Delta N Z 50_{t-i} \\
& +\sum_{i=1}^{q_{4}} \varphi_{5 i} \Delta S S E_{t-i}+\delta E C T_{t-1}+\varepsilon_{t}
\end{aligned}
$$

Eşitlikteki ECT (Error Correction Term) değişkeni hata düzeltme terimidir ve uzun dönem katsayı tahmininde kullanılan regresyon denkleminin hata terimlerini ifade etmektedir. ARDL modelindeki uzun dönem değişkenlerin $\left(\lambda_{\mathrm{k}}\right)$ yerine uzun dönem ilişki tahmini denkleminin gecikmeli değerleri koyularak Hata Düzeltme Modeli elde edilir. Analiz sonucunda ECT değişkenin katsayısının negatif ve istatistiksel olarak anlamlı olması beklenmektedir. Hata Düzeltme Modeli ile tahmin edilen katsayılar, kısa dönem ilişkiyi ifade etmektedirler. ECT değişkenin katsayısı kısa dönem şokların, uzun dönemde düzelme hızını göstermektedir.

\section{Analiz ve Bulgular}

Analize dahil edilen borsa endekslerine ait doğal logaritması alınmış 132 aylık kapanış fiyat serilerinin tanımlayıcı istatistikleri Tablo 1'de sunulmuştur.

Tablo 1: Tanımlayıcı İstatistikler

\begin{tabular}{|l|l|l|l|l|l|}
\hline & XU100 & KOSPI & N225 & NZ50 & SSE \\
\hline Ortalama & 11.19863 & 7.585430 & 9.573712 & 8.557057 & 7.913984 \\
\hline Ortanca & 11.24021 & 7.599404 & 9.654919 & 8.556572 & 7.949570 \\
\hline Maks. Değer & 11.69131 & 7.850283 & 10.09080 & 9.349398 & 8.436361 \\
\hline Min. Değer & 10.08692 & 6.968879 & 8.931740 & 7.832934 & 7.590453 \\
\hline Std. Sapma & 0.305038 & 0.143019 & 0.352733 & 0.421204 & 0.182025 \\
\hline Çarpıklık & -1.176 .366 & -1.457 .767 & -0.197017 & 0.126838 & 0.038016 \\
\hline Basıklık & 5.132344 & 6.964394 & 1.502510 & 1.753389 & 2.657415 \\
\hline Jarque-Bera & 55.45229 & 133.1922 & 13.18756 & 8.901142 & 0.677299 \\
\hline Olasılık & 0.000000 & 0.000000 & 0.001369 & 0.011672 & 0.712732 \\
\hline Gözlem Sayısı & 132 & 132 & 132 & 132 & 132 \\
\hline
\end{tabular}

Tablo 1 incelendiğinde, Jarque Berra test istatistiğine göre analize dahil edilen endekslere ait kapanış verilerinin logaritmik serilerinin, SSE endeksi hariç, normal dağıldığı hipotezi \%1 anlamlılık düzeyinde reddedilmektedir. Basıklık ve çarpıklık değerleri de bu bulguyu desteklemektedir. Normal dağılan serilerde çarpıklık değeri 0, basıklık değeri ise 3 olmaktadır. Endekslerin logaritmik kapanış fiyatlarına ait korelasyon verileri Tablo 2'de sunulmuştur.

Tablo 2: Korelasyon Tablosu

\begin{tabular}{|l|l|l|l|l|l|}
\hline & XU100 & KOSPI & N225 & NZ50 & SSE \\
\hline XU100 & 1.000000 & & & & \\
\hline KOSPI & 0.914783 & 1.000000 & & & \\
\hline N225 & 0.821331 & 0.681251 & 1.000000 & & \\
\hline NZ50 & 0.849955 & 0.703228 & 0.947349 & 1.000000 & \\
\hline SSE & 0.344420 & 0.316843 & 0.510578 & 0.406854 & 1.000000 \\
\hline
\end{tabular}

Tablo 2 incelendiğinde, BİST100 Endeksinin, Güney Kore KOSPI endeksi ile \%91,48; Japonya Nikkei 225 endeksi ile \%82,13; Yeni Zelanda NZ50 endeksi ile \%84,99 ve Çin SSE endeksi ile \%34,44 korelasyona sahip olduğu anlaş1lmaktadır. Güney Kore, Japonya ve Yeni Zelanda 
borsaları ile yüksek korelasyona sahip Borsa İstanbul, Çin borsası ile ise nispeten düşük korelasyona sahiptir.

\subsection{Birim Kök (Unit Root) Testi}

Eşbütünleşme analizi yapılmadan önce tüm logaritmik serilerin durağanlık testi yapılmıştır. Durağanlık testi için Augmented Dickey Fuller test istatistiği kullanılmıştır. Tablo 3'te, her bir logaritmik endeks kapanış fiyatları serisinin düzeyi ve birinci farkları için yapılmış Augmented Dickey Fuller test sonuçları yer almaktadır.

Tablo 3: Augmented Dickey Fuller Test Sonuçları

\begin{tabular}{|c|c|c|c|c|c|c|c|c|}
\hline \multirow{4}{*}{ Endeksler } & \multirow{2}{*}{\multicolumn{4}{|c|}{$\begin{array}{l}\text { Düzey } \\
\mathrm{H}_{0} \text { : Seride birim kök vardır. } \\
\mathrm{H}_{1} \text { : Seride birim kök yoktur. }\end{array}$}} & \multicolumn{4}{|l|}{ 1. Farklar } \\
\hline & & & & & \multicolumn{4}{|c|}{$\begin{array}{l}\mathrm{H}_{0} \text { : Serinin birinci farkında birim kök vardır. } \\
\mathrm{H}_{1} \text { : Serinin birinci farkında birim kök yoktur. }\end{array}$} \\
\hline & \multicolumn{2}{|c|}{ Sabit Terimli } & $\begin{array}{l}\text { Sabit } \\
\text { Trendli }\end{array}$ & Terin & \multicolumn{2}{|l|}{ veSabit Terimli } & \multicolumn{2}{|c|}{$\begin{array}{ll}\text { Sabit } & \text { Terimli } \\
\text { Trendli } & \end{array}$} \\
\hline & t Değeri & Olasılık & t Değeri & Olasılık & t Değeri & Olasılık & t Değeri & Olasılık \\
\hline XU100 & $-3,26635$ & 0,01 & $-4,15681$ & $0,0068^{*}$ & $-11,38762$ & & $-11,56307$ & $0,0000^{*}$ \\
\hline KOSPI & $-3,80558$ & $0,0037 *$ & $-3,93046$ & $0,0134 *$ & $-12,46818$ & $0,0000 *$ & $-12,79216$ & $0,0000 *$ \\
\hline N225 & $-1,06860$ & 0,7268 & $-2,24282$ & 0,4617 & $-11,26829$ & $0,0000 *$ & $-11,24125$ & $0,0000^{*}$ \\
\hline NZ50 & 0,52441 & 0,9870 & $-2,87931$ & 0,1727 & $-11,23051$ & $0,0000 *$ & $-11,17753$ & $0,0000^{*}$ \\
\hline $\mathbf{E}$ & $-2,49978$ & 01178 & -249026 & 0.3325 & -10.05787 & $0.0000 *$ & -10.02450 & $00000 *$ \\
\hline
\end{tabular}

Tabloda 3'te sunulan veriler incelendiğinde XU100 ve KOSPI endekslerinin düzeyde durağan I(0); N225, NZ50 ve SSE endekslerinin ise birinci farklarının durağan I(1) olduğu anlaşılmaktadır. $\mathrm{Bu}$ durumda Engle-Granger ve Johansen Eşbütünleşme Testleri uygulanamamaktadır. Bu sebeple, çalışmada serilerin aynı düzeyde durağan olması şartını taşımayan Gecikmesi Dağıtılmış Otoregresif Model (Autoregressive Distributed Lag Model - ARDL) kullanılmıştır. Söz konusu modelde bağımlı ya da bağımsız değişkenlerin, düzeyde ya da birinci farklarında durağan olması şartı aranmamaktadır. (Pesaran vd. 2001:291).

\subsection{Panel ARDL Modeli - Eșbütünleşme Analizi}

ARDL modelinin tahmin edilebilmesi için durağanlık seviyesi belirlenmiş serilerin optimum gecikme uzunlukları tahmin edilmelidir. Akaike Bilgi Kriterine göre tahmin edilen en iyi 20 modelin gecikme uzunlukları Şekil 1'de gösterilmektedir.

Şekil 1: Akaike Bilgi Kriteri ile Tahmin Edilen En İyi 20 Model

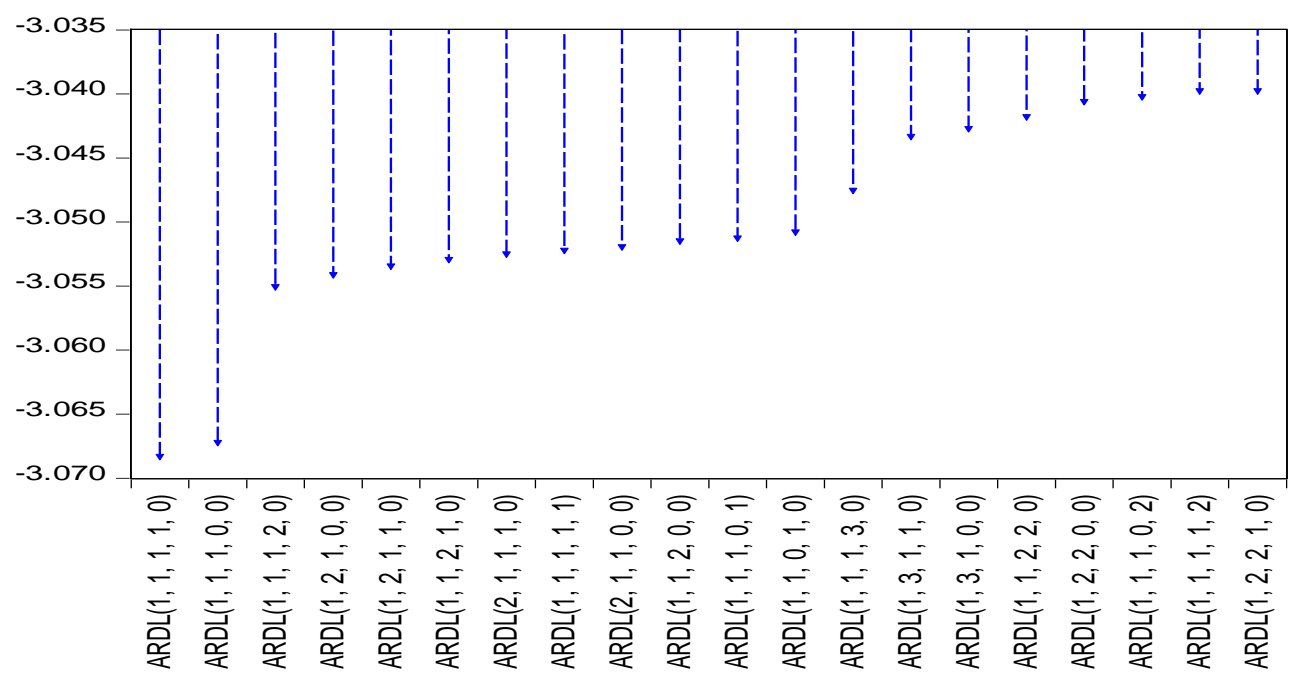


Şekil 1 incelendiğinde, en uygun ARDL modelinin ARDL $(1,1,1,1,0)$ modeli olduğu anlaşılmaktadır. Bu durumda bağımlı değişken (XU100) için en uygun gecikme uzunluğu 1 olarak tespit edilirken; bağımsız değişkenler (KOSPI, N225, NZ40 ve SSE) için ise sırasıyla 1, 1, 1 ve 0 gecikme uzunluğu uygun bulunmuştur.

Uygun gecikme uzunluğuna karar verildikten sonra ARDL denklemi için Sınır (Bounds) Testi uygulanmıştır. Wald Test ile hesaplanmış Sınır Testi sonuçları Tablo 4'te sunulmuştur.

Tablo 4: Sınır (Bounds) Testi Sonuçları (F-istatistiği)

\begin{tabular}{|c|c|c|c|c|c|}
\hline \multirow{4}{*}{$\begin{array}{l}\text { Sınır (Bound) } \\
\text { İstatistiği }\end{array}$} & \multirow{4}{*}{ Değer } & \multirow{2}{*}{\multicolumn{4}{|c|}{ Sınır (Bound) Test Kritik Değerleri }} \\
\hline & & & & & \\
\hline & & \multicolumn{2}{|c|}{$\begin{array}{l}\% 5 \text { Anlamlılık Düzeyi } \\
\text { için } \\
\text { Kritik Sınırlar }\end{array}$} & \multicolumn{2}{|c|}{$\begin{array}{l}\% 1 \text { Anlamlılık Düzey } \\
\text { için } \\
\text { Kritik Sınırlar }\end{array}$} \\
\hline & & $\mathrm{I}(0)$ & $\mathrm{I}(1)$ & $\mathrm{I}(0)$ & $\mathrm{I}(1)$ \\
\hline \multirow{2}{*}{$\begin{array}{l}\text { Hesaplanan F İstatistiği } \\
\text { Olasılık }\end{array}$} & 4,0916 & 2,86 & 4,01 & 3,74 & 5,06 \\
\hline & 0,0008 & \multicolumn{4}{|c|}{ Kaynak: Pesaran, Shin ve Smith, 2001: 300.} \\
\hline
\end{tabular}

Tablo 4 incelendiğinde, ARDL Sınır Testi sonucunda hesaplanan F-istatistik değeri, Pesaran, vd. (2001)'nin \%5 anlamlılık düzeyi için hesaplamış olduğu kritik değerlerin üst sınırını aşttğından dolayı $(4,09>4,01)$; eşbütünleşme yoktur (sıfir) hipotezi reddedilmektedir. Dolayısıyla, analize dahil edilen borsalar arasında eşbütünleşmenin, başka bir deyişle uzun vadeli bir ilişkinin var olduğu sonucuna ulaşılmaktadır. Bu durum, borsaların birlikte hareket ettiği ve birbirlerinden bağımsız olmadıkları anlamına gelmektedir.

Karar verilen optimal gecikme uzunluklarına göre oluşturulmuş ARDL $(1,1,1,1,0)$ Modeli tahmin sonuçları Tablo 5'te verilmiştir.

Tablo 5: ARDL $(1,1,1,1,0)$ Modelinin Tahmin Sonuçları

\begin{tabular}{|c|c|c|c|c|}
\hline \multicolumn{5}{|c|}{ Bağımlı Değișken: XU100 } \\
\hline \multicolumn{5}{|c|}{ Metot: ARDL } \\
\hline \multicolumn{5}{|c|}{ Örneklem (düzeltilmiş): 2009M02 - 2019M12 } \\
\hline \multicolumn{5}{|c|}{ Gözlem Sayısı: 131 (düzeltme sonrası) } \\
\hline \multicolumn{5}{|c|}{ Model Seçim Metodu: Akaike Bilgi Kriteri (AIC) } \\
\hline \multicolumn{5}{|c|}{ Seçilen Model: ARDL(1, 1, 1, 1, 0) } \\
\hline Değişkenler & Katsayı & Standart Hata & t-istatistiği & Olasılık \\
\hline XU100(-1) & 0.797939 & 0.053029 & 1.504 .731 & 0.0000 \\
\hline KOSPI & 0.649269 & 0.137770 & 4.712 .692 & 0.0000 \\
\hline KOSPI(-1) & -0.461122 & 0.141477 & -3.259 .345 & 0.0014 \\
\hline N225 & 0.177849 & 0.106841 & 1.664 .610 & 0.0986 \\
\hline N225(-1) & -0.193120 & 0.106736 & -1.809 .315 & 0.0729 \\
\hline NZ50 & 0.454923 & 0.189780 & 2.397 .101 & 0.0180 \\
\hline NZ50(-1) & -0.373098 & 0.192577 & -1.937 .398 & 0.0550 \\
\hline SSE & -0.010485 & 0.030025 & -0.349216 & 0.7275 \\
\hline $\mathbf{C}$ & 0.366327 & 0.337333 & 1.085 .951 & 0.2796 \\
\hline $\mathbf{R}^{2}$ & 0.972066 & F-istatistiği & & 5.306 .854 \\
\hline Düzeltilmiş $\mathbf{R}^{2}$ & 0.970235 & Olasılık (F-ista & & 0.000000 \\
\hline
\end{tabular}

ARDL modelinin tanısal test sonuçları Tablo 6'da sunulmuştur. Varsayım testlerinden normal dağılım için Jarque Bera, otokorelasyon için Breusch-Godfrey Seri Korelasyon Testi, değiş̧en varyans için ise White Testi uygulanmıştır. 
Tablo 6: ARDL $(1,1,1,1,0)$ Modeli Tanısal Test Sonuçları

\begin{tabular}{|c|c|c|c|}
\hline \multicolumn{4}{|c|}{ Breusch-Godfrey Seri Korelasyon Testi } \\
\hline F-istatistiği & 0.022816 & Olasılık F(1,121) & 0.8802 \\
\hline Gözlenen $\mathrm{R}^{2}$ & 0.024697 & Olasılık Ki-Kare(2) & 0.8751 \\
\hline \multicolumn{4}{|c|}{ Jarque-Bera Normallik Testi } \\
\hline JB-istatistiği & 2,044188 & Olasılık & 0,3598 \\
\hline \multicolumn{4}{|c|}{ White Değissen Varyans Testi } \\
\hline F-istatistiği & 1,311055 & Olasilı F(2,115) & 0,1494 \\
\hline Gözlenen $\mathrm{R}^{2}$ & 44,90655 & Olasılık Ki-Kare(2) & 0,1744 \\
\hline
\end{tabular}

Varsayım testlerinin sonuçları incelendiğinde $\mathrm{H}_{0}$ hipotezleri reddedilememektedir. Başka bir deyişle modelin hata terimleri normal dağılmakta, hata terimlerinin otokorelasyon veya değişen varyans problemi bulunmamaktadır. Modelin geçerli olabilmesi için yapılması gereken bir diğer test ise modelin kararlılığını (stability) ölçen yapısal değişiklik testidir. Kararlılık testi olarak CUSUM ve CUSUM-SQ (CUSUM of Squares) testleri kullanılmıştır. Test sonuçları Şekil 2'de gösterilmiştir.

Şekil 2: CUSUM ve CUSUM-SQ Test Grafikleri
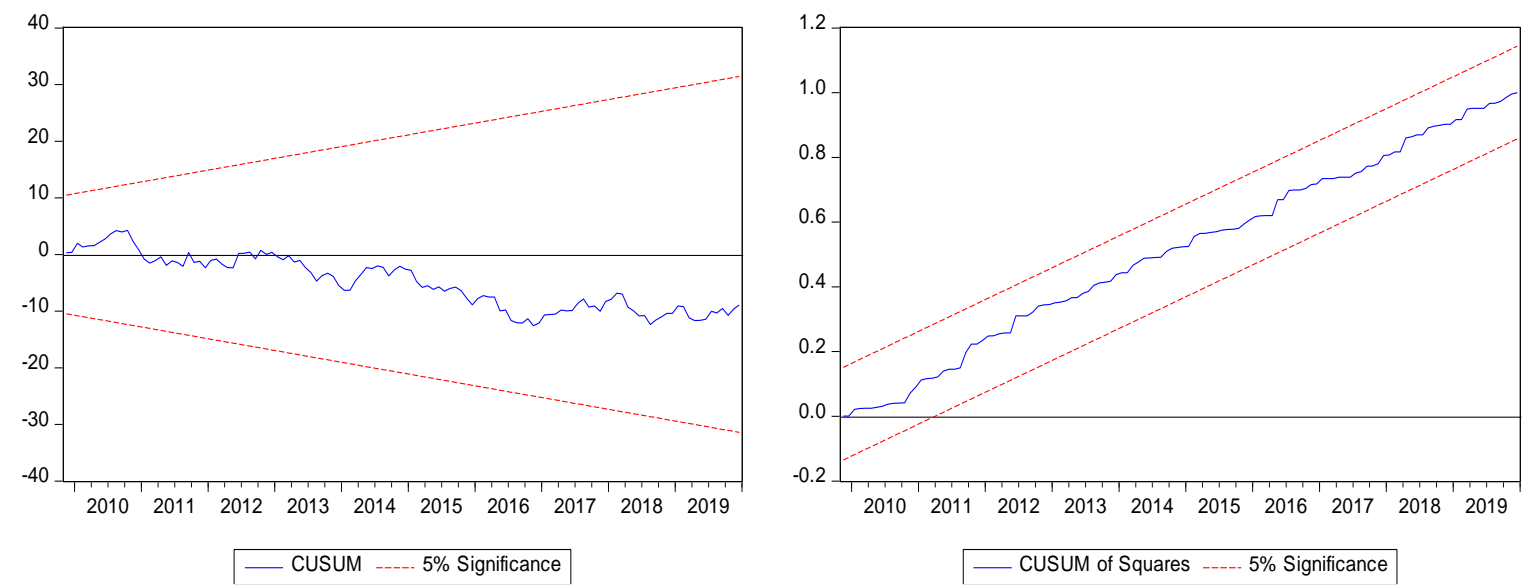

Test grafikleri incelendiğinde, çizgi grafiğgin $\% 5$ anlamlılık düzeyi için belirlenmiş kesikli kırmızı çizgi ile gösterilen sınırlar içerisinde kaldığ sahip olmadığı ve kararlı olduğu gözükmektedir.

\subsubsection{Uzun Dönem İliş̧i Analizi}

ARDL modeli uzun dönem ilişki ve kısa dönemli ilişkiyi içerisinde barındırmaktadır. Analize dahil edilen değişkenler arasındaki uzun dönem ilişkilere ait katsayılar ve olasılık değerleri Tablo 7'de gösterilmiştir.

Tablo 7: Uzun Dönem İlişki Tahmini

\section{Uzun Dönem İlişki Katsayıları}

\begin{tabular}{|l|l|l|l|l|}
\hline Değişken & Katsayı & Std. Hata & t-istatistiği & Olasıllk \\
\hline SSE & -0.051891 & 0.147567 & -0.351645 & 0.7257 \\
\hline NZ50 & 0.404950 & 0.187016 & 2.165321 & 0.0323 \\
\hline N225 & -0.075575 & 0.226023 & -0.334370 & 0.7387 \\
\hline KOSPI & 0.931137 & 0.257140 & 3.621130 & 0.0004 \\
\hline C & 1.812948 & 1.849374 & 0.980304 & 0.3289 \\
\hline
\end{tabular}


Tablo 7 incelendiğinde, uzun dönemde Borsa İstanbul ile Kore Borsası (KOSPI)'nın \%1, Yeni Zelanda Borsası (NZ50)'nın ise \%5 anlamlılık düzeyinde ile pozitif ve istatistiksel olarak anlamlı bir ilişkiye sahip olduğu; buna karşın Japon Borsası (N225) ve Çin Borsası (SSE)'nın ise Borsa İstanbul ile uzun dönemli ilişkisinin anlamlı olmadığı anlaşılmaktadır. Modelin hata terimleri normal dağılmaktadır, otokorelasyon ve değişen varyans problemi yoktur.

Borsa İstanbul ile Yeni Zelanda ve Güney Kore borsaları uzun dönemde eşbütünleşiktir. Dolayısı ile, birbirini takip eden bu borsalar, birbirinin alternatifi konumundadır. Başka bir deyişle, söz konusu borsalar, uzun dönemde Borsa İstanbul'a göre önemli ölçüde daha iyi veya daha kötü göreceli performansa sahip olmayacaklardır. Borsa İstanbul'da yatırıma sahip olan bir yatırımcının, uluslararası çeşitlendirme amacı ile uzun dönemde Güney Kore ve Yeni Zelanda borsası yerine Japon ve/veya Çin Borsasına yatırım yapması önerilebilir.

\subsubsection{Kısa Dönemli İlişki Analizi}

Eşbütünleşme bulgusuna ulaşıldıktan ve uzun dönem ilişki katsayıları tahmin edildikten sonra, ARDL metodolojisinin bir sonraki aşaması kısa dönemli ilişki katsayılarının tahmin edilmesidir. $\mathrm{Bu}$ amaçla uzun dönem ilişki tahmini amacıyla kurulan regresyon denkleminin hata terimlerinin açıklayıcı değişken olarak eklendiği (ECT - Error Correction Term) bir Hata Düzeltme Modeli (Error Correction Model) oluşturulur. Kurulan Hata Düzeltme Modeli, kısa dönem ilişki katsayıları ve olasılık değerleri Tablo 8'de sunulmaktadır.

Tablo 8: Hata Düzeltme Modeli Tahmin Sonuçları

\begin{tabular}{|l|l|l|l|l|}
\hline \multicolumn{5}{|l|}{ Kısa Dönem İlişki Katsayıları } \\
\hline Değişken & Katsayı & Std. Hata & t-istatistiği & Olasılık \\
\hline$\Delta$ SSE & -0.053088 & 0.070434 & -0.753720 & 0.4525 \\
\hline$\Delta$ NZ50 & 0.462328 & 0.185153 & 2.497010 & 0.0139 \\
\hline$\Delta$ N225 & 0.190434 & 0.104960 & 1.814353 & 0.0721 \\
\hline$\Delta$ KOSPI & 0.664092 & 0.127387 & 5.213184 & 0.0000 \\
\hline C & 0.366947 & 0.079515 & 4.614831 & 0.0000 \\
\hline ECT & -0.202471 & 0.044075 & -4.593817 & 0.0000 \\
\hline ECTt-1 = XU100 & $-\mathbf{( - 0 . 0 5 1 9} *$ SSE + $\mathbf{0 . 4 0 5 0} * \mathbf{N Z 5 0}$ & $\mathbf{- 0 . 0 7 5 6} * \mathbf{N 2 2 5}+\mathbf{0 . 9 3 1 1} *$ KOSPI + 1.8129) \\
\hline
\end{tabular}

Tablo 8 incelendiğinde, Borsa İstanbul ile Kore Borsası arasında \%1, Yeni Zelanda Borsas1 arasında $\% 5$, Japon Borsası arasında ise $\% 10$ anlamlılık düzeyinde kısa dönemli ilişki olduğu sonucuna ulaşılmıştır. Borsa İstanbul ile Çin Borsası arasındaki kısa dönemli ilişki, uzun dönem ilişkiye paralel şekilde istatistiksel olarak anlamlı bulunmamıştır.

Hata Düzeltme Modelinin tahmin sonuçları için beklenen; ECT değişkeninin katsayısının negatif işaretli ve istatistiksel olarak anlamlı olmasıdır. Tablo incelendiğinde ECT değişkeninin beklenen şartları sağladığı görülmektedir.

\section{Sonuç}

Klasik portföy seçim modellerinin kovaryansa dayalı çeşitlendirme yöntemleri, salt ulusal sermaye piyasalarına yatırım yapan bireysel ve kurumsal yatırımcıların sistematik riski elimine etmesine olanak sağlamamaktadır. Aynı ülke borsasında işlem gören tüm hisse senetleri aynı sistematik risk unsurlarından etkilendiğinden, uluslararası sermaye piyasalarında işlem gören hisse senetleri kullanılarak çeşitlendirilmiş portföyler, yalnızca ulusal hisse senetlerinden oluşan portföylere göre aynı risk düzeyinde daha yüksek getiri elde etmeyi ya da aynı getiri düzeyinde daha az riske katlanmayı sağlayabilirler. Ancak bu durum yatırım yapılacak yabancı hisse senetleri ile ulusal hisse senetlerinin pozitif korelasyona sahip olmaması şartına bağlıdır. Başka bir deyişle kaynakların dağıtıldığ 1 sermaye piyasaları birbirleri ile entegre olmamalıdırlar. Eşbütünleşme, kovaryansa dayalı geleneksel çeşitlendirme yöntemlerinin uzun dönem etkinliğini ortadan 
kaldırmaktadır. Bu sebeple uluslararası sermaye piyasaları arasındaki entegrasyon, riskini minimize etmek ya da arbitraj avantajlarından faydalanmak isteyen sermaye piyasası yatıımcıları açısından önem arz etmektedir.

Yirminci yüzyılın son çeyreğinde hızlanan sermaye serbestleşmesi ve teknolojik gelişmeler ile uluslararası piyasalara erişim giderek kolaylaşmıştır. Bu gelişmeler, portföylerinde uluslararası çeşitlendirmeye gitmek isteyen yatırımcıların yabancı piyasalarda yaptıkları işlemlerin sayısının ve büyüklüğünün gün geçtikçe artmasında önemli rol oynamıştır. Ancak yatırımcıların gelişi güzel yaptığı yatırımlar çoğunlukla bir risk ya da getiri avantajı sağlamamaktadır. Bu sebeple günümüz finans yazınında, farklı ülkelerdeki borsalar arasındaki ilișkilere dair çalıșmalar önem kazanmaktadır. Söz konusu çalışmalarda kullanılan analizlerden biri de uluslararası sermaye piyasalarının uzun dönemde bağımlılığını test eden eşbütünleşme analizidir. Eşbütünleşme ilişkinin araştırılması amacı ile en sik kullanılan modeller arasında, eşbütünleşme ve hata düzeltme aşamalarından oluşan iki aşamalı Engle-Granger Eşbütünleşme Testi (Engle \& Granger, 1987) ve Johansen Eşbütünleşme Testi (Johansen, 1988) öne çıkmaktadır. Söz konusu testler analize dahil edilen endeks serilerinin aynı düzeyde durağan olması şartını aramaktadır.

$\mathrm{Bu}$ çalışmada, endeks serilerinin aynı düzeyde durağan olması şartını aramayan Gecikmesi Dağıtılmış Otoregresif Model (Autoregressive Distributed Lag Model - ARDL) kullanılarak Borsa İstanbul ile en büyük Asya Pasifik sermaye piyasaları arasından seçilen Çin Borsası, Japon Borsası, Güney Kore Borsası ve Yeni Zelanda borsası arasındaki uzun ve kısa dönemli ilişkiler araştırılmıştır. ARDL modelinin tahmin edilebilmesi için durağanlık seviyesi belirlenmiş serilerin optimum gecikme uzunlukları belirlenmelidir. Akaike Bilgi Kriterine göre karar verilen en uygun gecikme uzunlukları göz önünde bulundurularak tahmin edilen ARDL modeli ile söz konusu borsalar arasındaki eşbütünleşme Sınır Testi ile araştırılmıştır. Eşbütünleşmenin varlığı ortaya koyulduktan sonra uzun ve kısa dönem ilişki katsayıları tahmin edilmiştir.

Çalışmada serilerin durağanlık için yapılan birim kök testi (ADF) sonuçlarına göre XU100 ve KOSPI endekslerinin düzeyde durağan $\mathrm{I}(0)$; N225, NZ50 ve SSE endekslerinin ise birinci farklarının durağan I(1) olduğu anlaşılmıştır. Oluşturulan ARDL modeli için Akaike Bilgi Kriterine göre belirlenen gecikme uzunlukları XU100, KOSPI, N225 ve NZ50 değişkenleri için 1, SSE değişkeni için ise 0'dır. Belirlenen optimal gecikmelere kurulan ARDL modeli (ARDL $(1,1,1,1,0))$ 'nin Sınır Testi sonucunda hesaplanan F istatistiği 4,0916'dır. F-istatistik değeri, Pesaran, Shin ve Smith'in (2001), \%5 anlamlılık düzeyi için hesaplamış olduğu kritik değerlerin üst sınırını aştığından dolayı $(4,09>4,01)$ analize dahil edilen borsalar arasında eşbütünleşmenin, başka bir deyişle uzun vadeli bir ilişkinin var olduğu sonucuna ulaşılmıştır.

ARDL modeli uzun dönem ilişki ve kısa dönemli ilişkiyi içerisinde barındırmaktadır. $\mathrm{Bu}$ sebeple uzun dönem ve kısa dönem ilişki katsayıları ayrı ayrı tahmin edilmiştir. Analiz sonuçlarına göre uzun dönemde Borsa İstanbul (XU100) ile Güney Kore Borsası (KOSPI)'nın \%1, Yeni Zelanda Borsası (NZ50)'nın ise \%5 anlamll1ık düzeyinde pozitif ve istatistiksel olarak anlamlı bir ilişkiye sahip olduğu; buna karşın Japon Borsası (N225) ve Çin Borsası (SSE)'nın ise Borsa İstanbul ile uzun dönemli ilişkisinin anlamlı olmadığı sonucu ortaya çıkmaktadır. Başka bir deyişle, Güney Kore ve Yeni Zelanda Borsaları, uzun dönemde Borsa İstanbul'a göre önemli ölçüde daha iyi veya daha kötü göreceli performansa sahip olmayacaklardır. Ancak Japon ve Çin borsaları, Borsa İstanbul yatırımcıları için iyi birer uluslararası çeşitlendirme alternatifi olarak öne çıkmaktadır.

Eşbütünleşme ve uzun dönem ilişki bulgusuna ulaşılan ARDL modelinin bir sonraki aşamasında kısa dönemli ilişkinin var olup olmadığı test edilmiştir. Bu amaçla uzun dönem ilişki tahmininin yapıldığ 1 regresyonun hata terimleri bir değişken olarak kullanılarak (ECT - Error Correction Term) bir Hata Düzeltme Modeli (Error Correction Model) oluşturulmuştur. Analiz sonucunda Borsa İstanbul ile Kore Borsas1 arasında \%1, Yeni Zelanda Borsası arasında \%5, Japon Borsası arasında ise \%10 anlamlılık düzeyinde kısa dönemli ilişki olduğu sonucuna ulaşılmıştır. 
Borsa İstanbul ile Çin Borsası arasındaki kısa dönemli ilişki, uzun dönem ilişkiye paralel şekilde istatistiksel olarak anlamsız bulunmuştur.

Analiz sonuçlarına göre Borsa İstanbul'da yatırıma sahip olan bir yatırımcının, uluslararası çeşitlendirme amacı ile uzun dönemde Güney Kore ve Yeni Zelanda borsası yerine Japon ve/veya Çin Borsasına yatırım yapması önerilebilir. Kısa dönemde ise Güney Kore Borsası, Yeni Zelanda Borsası ve Japon Borsası, Borsa İstanbul ile bağımlı hareket ettiğinden, çeşitlendirme ya da normal üstü getiri elde etme olanağı bulunmamaktadır. Türk sermaye piyasasına yatırım yapan bir yatırımcı için, kısa dönemde, uzun dönem sonuçlarına paralel olarak Çin Borsası, en iyi uluslararası çeşitlendirme alternatifi olarak göze çarpmaktadır.

\section{Kaynakça}

Akel, V. (2015). Kırılgan Beşli Ülkelerinin Hisse Senedi Piyasaları Arasındaki Eşbütünleşme Analizi. Uluslararası Yönetim Iktisat ve Işsletme Dergisi, 11(24), 99-118. https://doi.org/10.17130/ijmeb.2015.11.24.719

Akıncı, G. Y. ve Küçükçaylı, F. M. (2018). Borsalar-Arası Karşılıklı Bağımlılık: Asya Ve Avrupa Borsalar1 Birbirlerini Etkiliyor Mu? Uluslararası İktisadi ve İdari İnclemeler Dergisi, 18. EYİ Özel Sayısı, 721-734. https://doi.org/10.18092/ulikidince.346453

Belloumi, M. (2014). The relationship between trade, FDI and economic growth in Tunisia: An application of the autoregressive distributed lag model. Economic Systems, 38(2), 269-287. https://doi.org/10.1016/j.ecosys.2013.09.002

Bozoklu, Ş. ve Saydam, İ. M. (2010, Temmuz-Aralı). BRIC Ülkeleri ve Türkiye Arasındaki Sermaye Piyasaları Entegrasyonunun Parametrik ve Parametrik Olmayan Eşbütünleşme Testleri ile Analizi. Maliye Dergisi(159), 416-431.

Boztosun, D. ve Çelik, T. (2011). Türkiye Borsasının Avrupa Borsaları İle Eşbütünleşme Analizi. Süleyman Demirel Üniversitesi İktisadi ve İdari Bilimler Fakültesi Dergisi, 16(1), 147-162.

Bulut, Ş. ve Özdemir, A. (2012). İstanbul Menkul Kıymetler Borsası ve "Dow Jones Industrial" Arasındaki İlişki: Eşbütünleşme Analizi. Yönetim ve Ekonomi, 19(1), 211-224.

Chan, K. C., Gup, B. E. ve Pan, M.-S. (1997). International Stock Market Efficiency and Integration: A Study of Eighteen Nations. Journal of Business Finance \& Accounting, 24(6), 803-813. https://doi.org/10.1111/1468-5957.00134

Choudhry, T. (1997). Stochastic Trends in Stock Prices: Evidence from Latin American Markets. Journal of Macroeconomics, 19(2), 285-304. https://doi.org/10.1016/s0164-0704(97)000165

Enders, W. (2014). Applied Econometric Time Series. Wiley Series in Probability and Statistics.

Engle, R. F. ve Granger, C. W. (1987, March). Co-Integration and Error Correction: Representation, Estimation, and Testing. Econometrica, 55(2), 251-276. https://doi.org/10.2307/1913236

Ergün, B., Samırkaş, M. C. ve Cihangir, M. (2012). Türkiye Hisse Senedi Piyasasının Ortadoğu Ve Kuzey Afrika Hisse Senedi Piyasaları İle Entegrasyonu. 11. Ulusal İşletmecilik Kongresi, (s. 155-160). Konya. Ekim 10, 2019 tarihinde http://apbs.mersin.edu.tr/files/mustafa.can/Scientific_Meetings_002.pdf adresinden alınd1

Eyüboğlu, S. ve Eyüboğlu, K. (2019). Borsa İstanbul Sektör Endekslerinin Karş1lıklı Bağımlılıklarının Test Edilmesi. Erciyes Üniversitesi İktisadi ve İdari Bilimler Fakültesi Dergisi, 53, 246-253. https://doi.org/10.18070/erciyesiibd.345786 
Geyikçi, U. B. (2017). BİST ile Yükselen Piyasalara Ait Endeksler Arasındaki Eşbütünleşme be Nedenselliğin Test Edilmesi; Yatırımcılar Açısından Çeşitlendirme Fırsatları. International Journal of Human Sciences, 14(4), 3486-3503. https://doi.org/10.14687/jhs.v14i4.4943

Gilmore, C. G. ve McManus, G. M. (2003). Random-walk and efficiency tests of Central European equity markets. Managerial Finance, 29(4), 42-61. https://doi.org/10.1108/03074350310768283

Gökmen, O. ve Çömlekçi, İ. (2018). Turizm Endeksleri Arasındaki Eşbütünleşme İlişkisi. Seyahat ve Otel İsletmeciliği Dergisi / Journal of Travel and Hospitality Management, 15(2), 273 286. https://doi.org/10.24010/soid.453157

Gözbaşı, O. (2010, Ocak-Temmuz). İMKB ile Gelişmekte Olan Ülkelerin Hisse Senedi Piyasalarının Etkileşimi: Eşbütünleşme ve Nedensellik Yaklaşımı. Erciyes Üniversitesi İktisadi ve İdari Bilimler Fakültesi Dergisi(35), 99-118. https://doi.org/10.25287/ohuiibf.423114

Hallgren, F. ve Rehn, R. (2011, May1s 30). Stock market cointegration in Europe. ARC: http://arc.hhs.se/download.aspx?MediumId=1270 adresinden alındı

Jochum, C., Kirchgässner, G. ve Platek, M. (1999). “A long-run relationship between Eastern European stock markets? Cointegration and. Review of World Economics, 135(3), 454-479. https://doi.org/10.1007/bf02707335

Johansen, S. (1988, June-September). Statistical analysis of cointegration vectors. Journal of Economic Dynamics and Control, 12(2-3), 231-254. https://doi.org/10.1016/01651889(88) $90041-3$

Kasa, K. (1992). Common stochastic trends in international stock markets. Journal of Monetary Economics, 29(1), 95-124. https://doi.org/10.1016/0304-3932(92)90025-w

Khan, T. A. (2011). Cointegration of International Stock Markets: An Investigation of Diversification Opportunities. Undergraduate Economic Review, 8(1), 1-50.

Narayan, P. K. ve Smyth, R. (2005, Feb.). Cointegration of Stock Markets between New Zealand, Australia and the G7 Economies: Searching for Co-Movement under Structural Change. Australian Economic Papers, 44(3), 231-247. https://doi.org/10.1111/j.14678454.2005.00262.x

Nkoro, E. ve Uko, A. K. (2016). Autoregressive Distributed Lag (ARDL) cointegration technique: application and interpretation. Journal of Statistical and Econometric Methods, 5(4), 63-91.

Pesaran, M. H. ve Shin, Y. (1999). An Autoregressive Distributed Lag Modelling Approach to Cointegration Analysis. E. S. Strøm içinde, Econometrics and Economic Theory in the 20th Century: The Ragnar Frisch Centennial Symposium (Econometric Society Monographs) (s. 371-413). Cambridge: Cambridge University Press. https://doi.org/10.1017/cbo9781139052221.011

Pesaran, M. H., Shin, Y. ve Smith, R. J. (2001, May/June). Bounds testing approaches to the analysis of level relationships. Journal of Applied Econometrics, 16(8), 289-326. https://doi.org/10.1002/jae.616

Taufiq, C., Lin, L. ve Peng, K. (2007). Common stochastic trends among Far East stock prices: Effects of the Asian financial crisis. International Review of Financial Analysis, 16, $242-$ 261. https://doi.org/10.1016/j.irfa.2006.12.001

Thangamuthu, M. ve Karthikeyan, P. (2015). Cointegration and stock market interdependence: Evidence from South Africa, India and the USA. South African Journal of Economic and Management Sciences, 18(4), 475-485. https://doi.org/10.4102/sajems.v18i4.1029 
Vuran, B. (2010). IMKB 100 endeksinin uluslararası hisse senedi endeksleri ile ilişkisinin eşbütünleşim analizi ile belirlenmesi. İstanbul Üniversitesi İsletme Fakültesi Dergisi, 39(1), 154-168.

Wuthisatian, R. (2014). Cointegration of Stock Markets: The Case of Thailand. Review of Market Integration, 6(3), 297-320. https://doi.org/10.1177/0974929215582244

Yang, J., Khan, M. M. ve Pointer, L. (2003). Increasing Integration Between the United States and Other International Stock Markets? A Recursive Cointegration Analy. Emerging Markets Finance \& Trade, 39(6), 39-53. https://doi.org/10.1080/1540496x.2003.11052558 